\title{
KEBERHASILAN PENERAPAN SIA SEBAGAI VARIABEL PEMODERASI ATAS HUBUNGAN KOMITMEN ORGANISASIONAL DAN KINERJA (SURVEI PADA BUMN DI INDONESIA)
}

\author{
Adli \\ Universitas Mercubuana Jakarta \\ Email: adlianwar69@gmail.com
}

\begin{abstract}
The purposes of this study is to test: (1) the influence of organizational commitment on companies financial performance; and (2) the influence organizational commitment and success of implementation accounting information system both jointly on companies financial performance. The study was conducted survey method, consist of 38 BUMN in Indonesia, the sample was taken by using simple random sampling from populations. The collected were used questioners, and the validity and reliability of the data was tested before hypothesis testing. The data analysis for hypothesis testing using moderated regression analysis was processed by SPSS 16 software. The result of this study show that: (1) The organizational commitment significance effect on companies financial performance; and (2) The organizational commitment and success of implementation accounting information system both jointly significance effect on companies financial performance specially on ROA dimension.
\end{abstract}

Keywords: Organizational commitment, Success of Implementation Accounting Information System, and Companies Financial Performance.

\section{PENDAHULUAN}

Tingkat komitmen organisasional manajer dan karyawan perusahaan di Indonesia tergolong rendah. Berdasarkan survei tahun 2005 yang dilakukan Hay Group (konsultan yang berpusat di Boston USA) terhadap 5.080 manajer dan karyawan (termasuk BUMN) pada 31 perusahaan di Indonesia yang dipublikasikan dalam majalah Swasembada edisi II tanggal 26 Januari 2006, disimpulkan bahwa Indek Komitmen Karyawan Indonesia sangat rendah dan mendapatkan skor sebesar 63 dan menempati urutan ke 31 dibandingkan 32 negara yang di survei pada saat yang bersamaan. Skor tertinggi sebesar 87 diperoleh oleh Austria, Denmark, Finlandia, dan Mexico, kemudian skor paling rendah dan satu tingkat di bawah Indonesia diperoleh negara Jepang (Teguh Pambudi, 2006).

Dari hasil survei Hay Group tentang komitmen karyawan dijelaskan bahwa skor komitmen karyawan dan manajer perusahaan di Indonesia sebesar 63 adalah nilai keseluruhan dari partisipan yang di survei. Namun demikian, jika di lihat pada indeks masing-masing perusahaan yang di survei terdapat beberapa perusahaan yang memiliki indeks komitmen tinggi (di atas 80 poin). Dari 31 
perusahaan yang di survei, ada tiga perusahaan di Indonesia yang memiliki indeks komitmen tertinggi dan semuanya merupakan perusahaan asing dan bersifat multinasional, antara lain: PT. TNT Indonesia, sebuah perusahaan logistik internasional (index score 89), PT. Microsoft Indonesia, sebuah perusahaan produsen software komputer terkemuka (index score 88), dan PT. Hasta Rahayu Citra, sebuah perusahaan yang mengelola jaringan kafe internasional Hard Rock Kafe (index score 87) (Teguh Pambudi, 2006). Tabel 1 menunjukkan 10 besar perusahaan yang memiliki Indeks Komitmen Karyawan tertinggi di Indonesia berdasarkan hasil survei dari Konsultan Hay Group pada tahun 2006.

Tabel 1. Indeks Komitmen Karyawan pada 10 Besar Perusahaan di Indonesia

\begin{tabular}{|c|l|c|}
\hline No & \multicolumn{1}{|c|}{ Nama Perusahaan } & $\begin{array}{c}\text { Skor Indek Komitmen } \\
\text { Karyawan }\end{array}$ \\
\hline 1 & PT. TNT Indonesia & 89 \\
\hline 2 & PT. Microsoft Indonesia & 88 \\
\hline 3 & PT. HRC (Hard Rock Kafe) & 87 \\
\hline 4 & PT. Berca Hardyaperkasa & 80 \\
\hline 6 & PT. Indofood, Tbk & 79 \\
\hline 7 & PT. Dexa Medica & 74 \\
\hline 8 & PT. HM. Sampoerna, Tbk. & 74 \\
\hline 9 & PT. Bank Niaga, Tbk. & 73 \\
\hline 10 & PT. Pfizer Indonesia & 72 \\
\hline
\end{tabular}

Sumber: Teguh Pambudi (2006)

Tingkat komitmen organisasional manajer dan karyawan di duga mempengaruhi tingkat kinerja perusahaan. Menurut Chen, et.al. (2002), inti dari komitmen organisasional adalah loyalitas yang dapat mendorong seseorang untuk bekerja keras mengarahkan segala kemampuannya untuk mencapai tujuan perusahaan. Apabila individu-individu dalam organisasi saling bekerja keras dan selalu mengarahkan segala kemampuannya untuk tujuan perusahaan maka dalam jangka panjang akan berdampak terhadap kinerja perusahaan. Menurut Clercq and Rius (2007), komitmen organisasional yang dimiliki oleh seseorang diibaratkan seperti sebuah energi besar yang mendorong seseorang bekerja keras (effort) mencapai keberhasilan perusahaan yang pada akhirnya berdampak terhadap profitabiltas perusahaan. Kemudian Keller (1997), mengatakan bahwa komitmen organisasional dapat menciptakan kesamaan tujuan (goal congruence) antara seorang individu dengan perusahaan, kesamaan tujuan merupakan aspek mendasar untuk pencapaian kinerja perusahaan.

Keberhasilan penerapan SIA dan komitmen organisasional di duga saling berinteraksi dalam mempengaruhi kinerja keuangan perusahaan. Menurut Azhar (2007), efektivitas penerapan sistem informasi akuntansi di perusahaan di samping dapat meningkatkan kecepatan dan kualitas informasi yang dihasilkan untuk pengambilan keputusan, penerapan sistem informasi akuntansi juga dapat meningkatkan kualitas hubungan antar individu dalam organisasi tersebut. Kualitas hubungan antar individu adalah faktor utama peningkatan komitmen organisasional manajer dan karyawan, yang secara bersama-sama akan mendorong perusahaan menjadi lebih dinamis sehingga menghasilkan kinerja perusahaan. Menurut Romney and Steinbart (2009), penerapan sistem informasi 
akuntansi di perusahaan dapat memberi nilai tambah (value added) bagi pemakai dalam bentuk penyediaan berbagai informasi keuangan untuk kegiatan perencanaan, pengendalian dan pengambilan keputusan perusahaan. Adanya nilai tambah SIA akan meningkatkan kualitas komitmen organisasional yang pada akhirnya dapat meningkatkan kinerja perusahaan secara keseluruhan. Kemudian Gelinas, et. al. (1993), menyatakan bahwa keberhasilan penerapan sistem informasi akuntansi dapat mendorong perbaikan dalam operasi bisnis sehari-hari dan dapat meningkatkan kualitas pengambilan keputusan perusahaan. Perbaikan operasi bisnis, peningkatan pengambilan kualitas keputusan manajerial, serta komitmen komitmen organisasional yang tinggi dapat di duga akan mempunyai pengaruh besar untuk pencapaian kinerja perusahaan.

Studi tentang keberhasilan penerapan SIA masih sangat terbatas baik di Indonesia maupun di luar negeri. Sepanjang pengetahuan penulis belum ada penelitian sejenis yang dilakukan di Indonesia maupun di luar negeri dalam konteks ini. Penelitian ini bertujuan untuk mengkonfirmasi bahwa komitmen organisasional dan keberhasilan penerapan SIA akan saling berinteraksi dalam meningkatkan kinerja perusahaan. Sebagai sebuah bagian dari Sistem Informasi Manajemen, SIA diyakini sebagai alat efektif untuk mendukung keberhasilan perusahaan. Keberadaan penelitian ini diharapkan akan mendorong berkembangnya literatur SIA yang lebih luas dan holistik di masa yang akan datang.

\section{KAJIAN PUSTAKADAN PENGEMBANGAN HIPOTESIS}

\subsection{KAJIAN PUSTAKA}

Komitmen Organisasional

Menurut Mathis and Jackson (2004),

"organizational commitment is the degree to which employees believe in and accept organizational goals and desire to remain with the organizational".

Terdapat dua pandangan tentang dimensi komitmen organisasional, pertama pandangan Mowday et.al. (1982), dan kedua adalah pandangan Meyer and Allen (1991). Menurut Mowday, et.al. (1982), dimensi yang mendominasi operasionalisasi konsep komitmen organisasional meliputi tiga hal yaitu: (1) Identifikasi (identification); (2) Keterlibatan (involvement); dan (3) Loyalitas (loyality). Kemudian menurut Meyer and Allen (1991), komitmen organisasional adalah perasaan akan kewajiban karyawan untuk berada pada organisasi, perasaan tersebut dihasilkan dari internalisasi tekanan normatif individu pada saat masuk organisasi atau selanjutnya. Model Meyer and Allen (1991) mengidentifikasi tiga dimensi komitmen organisasional, yaitu: (1) Komitmen afektif (affective commitment); (2) Komitmen kontinyu (continuance commitment); dan (3) Komitmen normatif (normative commitment). 


\section{Keberhasilan Penerapan Sistem Informasi Akuntansi}

Menurut Torkzadeh and Doll (1998), keberhasilan penerapan sistem informasi akuntansi adalah penggunaan sistem (system use), yaitu penggunaan sistem informasi akuntansi untuk membantu penyelesaian pekerjaan sehari-hari. Kemudian menurut Etezadi and Farhoomand (1996), Kettinger and Lee (1995), dan Thong and Yap (1996), keberhasilan penerapan sistem informasi akuntansi adalah kepuasan pengguna (user satisfaction), yaitu tingkat kebermanfaatan yang diperoleh seorang pengguna atas sistem informasi akuntansi. Sedangkan menurut Gelderman (1998), keberhasilan penerapan sistem informasi akuntansi adalah intensitas penggunaan sistem (intended use) sistem informasi akuntansi dalam pekerjaan sehari-hari dan kepuasan pengguna (user satisfaction) atas pemakaian sistem informasi akuntansi. Kemudian and Straub et.al. (1995) mendefenisikan keberhasilan penerapan sistem informasi akuntansi sebagai intention use dan user satisfaction.

Dalam penelitian ini defenisi keberhasilan penerapan sistem informasi akuntansi merujuk kepada Straub, et.al. (1995) dan Gelderman (1998), dimana keberhasilan penerapan sistem informasi akuntansi adalah intensitas penggunaan (intended use) sistem informasi akuntansi dalam berbagai tugas manajerial dan kepuasan pengguna (user satisfaction) atas informasi yang dihasilkan oleh sistem informasi akuntansi.

Secara teori ada dua model komprehensif yang dapat dirujuk untuk dimensi keberhasilan penerapan sistem informasi akuntansi, yaitu: (1) Information Success Model dari Delone and McLean (1992); dan (2) Hierarchical Structural Model dari Drury and Farhoomand (1998). Disamping kedua model ini, Laudon and Laudon (2000) memberikan lima dimensi untuk mengukur keberhasilan penerapan sistem informasi akuntansi, dimensi-dimensi tersebut adalah: (1) Tingkat penggunaan yang tinggi (high level of system use); (2) Kepuasan pengguna terhadap sistem (user satisfaction on system); (3) Sikap yang positif (favorable attitude) pengguna terhadap sistem tersebut; (4) Tercapainya tujuan sistem informasi (achieved objectives ); dan (5) Imbal balik keuangan (financial payoff).

\section{Kinerja Keuangan Perusahaan}

Kinerja adalah catatan outcome yang dihasilkan dalam suatu periode. Kemudian Stolovitch and Keeps (1992) menjelaskan bahwa kinerja adalah seperangkat hasil yang biasanya merujuk pada pencapaian pelaksanaan pekerjaan yang dilakukan. Dalam penelitian ini pengertian kinerja keuangan perusahaan merujuk kepada Gomes (2003), di mana kinerja keuangan perusahaan adalah tingkat prestasi atau keberhasilan keuangan yang dicapai oleh suatu perusahaan pada suatu periode tertentu. Tingkat prestasi atau keberhasilan keuangan biasanya dikaitkan dengan tingkat laba yang diperoleh oleh perusahaan. Ukuran kinerja keuangan yang dipakai adalah profitabilitas, yang diartikan sebagai kemampuan perusahaan dalam menghasilkan laba. Adapun alasan menggunakan ukuran kinerja profitabilitas adalah: (1) Profitabilitas merupakan ukuran kinerja keuangan 
penting dan sering digunakan dalam penelitian untuk mengukur kinerja keuangan perusahaan (Barker and Cagwin, 2000; Salama, 2003; dan Cagwin and Bouman, 2000); (2) Profitabilitas dapat mengukur kinerja perusahaan secara keseluruhan dan dapat mengukur tingkat efisiensi dalam pengelolaan aset, kewajiban, dan ekuitas perusahaan (Fraser and Ormiston, 1998); dan (3) Pemegang saham lebih cenderung menggunakan profitabilitas, karena kestabilan harga saham sangat tergantung pada tingkat keuntungan yang diperoleh dan penerimaan dividen dimasa yang akan datang (Agus Sartono, 2001).

\subsection{PENGEMBANGAN HIPOTESIS}

Menurut Chen, et.al. (2002), inti dari komitmen organisasional adalah loyalitas yang dapat mendorong seseorang untuk bekerja keras mengarahkan segala kemampuannya untuk mencapai tujuan perusahaan. Apabila individu-individu dalam organisasi saling bekerja keras dan selalu mengarahkan segala kemampuannya untuk tujuan perusahaan maka dalam jangka panjang akan berdampak terhadap kinerja perusahaan. Menurut Clercq and Rius (2007), komitmen organisasional yang dimiliki oleh seseorang diibaratkan seperti sebuah energi besar yang mendorong seseorang bekerja keras (effort) mencapai keberhasilan perusahaan yang pada akhirnya berdampak terhadap profitabiltas perusahaan. Kemudian Keller (1997), mengatakan bahwa komitmen organisasional dapat menciptakan kesamaan tujuan (goal congruence) antara seorang individu dengan perusahaan, kesamaan tujuan merupakan aspek mendasar untuk pencapaian kinerja perusahaan.

Kemudian juga didapatkan bukti-bukti empiris bahwa komitmen organisasional berpengaruh terhadap peningkatan kinerja perusahaan, seperti penelitian yang dilakukan oleh: Rober T. Keller (1997), Li Yueh Chen (2004), Clercq and Rius (2007), dan Etty Murwaningsari (2008). Robert T. Keller (1997) melakukan penelitian tentang hubungan antara interaksi keterlibatan kerja dan komitmen organisasional terhadap kinerja tugas. Dari hasil survei terhadap 532 orang akademisi dan tenaga teknik pada empat perusahaan penelitian dan pengembangan (R\&D), disimpulkan bahwa ada hubungan interaksi antara keterlibatan kerja dan komitmen organisasional terhadap kinerja tugas. Li Yueh Chen (2004) melakukan penelitian tentang hubungan antara budaya organisasi, perilaku kepemimpinan, komitmen organisasional, kepuasan kerja, dan kinerja tugas. Dari hasil survei terhadap 929 karyawan dari 57 perusahaan jasa dan manufaktur kecil dan menengah di Cina, Li Yueh Chen (2004) menemukan bahwa komitmen organisasional berhubungan signifikan dengan kinerja tugas. Clercq and Rius (2007) melakukan penelitian tentang hubungan antara status kerja (work status), iklim organisasi (organizational climate), sikap strategik perusahaan (firm strategic posture), komitmen organisasional, dan usaha (effort). Dari hasil survei terhadap 863 karyawan dari berbagai perusahaan kecil dan menengah di Meksiko, Clercq and Rius (2007) menyimpulkan bahwa komitmen organisasional berhubungan secara signifikan terhadap usaha (effort). Kemudian Etty (2008) melakukan penelitian tentang pengaruh moderasi komitmen organisasional dan keadilan prosedural, terhadap hubungan antara partisipasi 
anggaran dan kinerja manajerial. Dari hasil survei terhadap 32 manajer berbagai perusahaan di Indonesia, disimpulkan bahwa komitmen organisasional adalah variabel pemoderasi yang memperkuat hubungan antara partisipasi anggaran dan kinerja manajerial.

Keberhasilan penerapan SIA dan komitmen organisasional di duga saling berinteraksi dalam mempengaruhi kinerja keuangan perusahaan. Menurut Azhar (2007), efektivitas penerapan sistem informasi akuntansi di perusahaan di samping dapat meningkatkan kecepatan dan kualitas informasi yang dihasilkan untuk pengambilan keputusan, penerapan sistem informasi akuntansi juga dapat meningkatkan kualitas hubungan antar individu dalam organisasi tersebut. Kualitas hubungan antar individu adalah faktor utama peningkatan komitmen organisasional manajer dan karyawan, yang secara bersama-sama akan mendorong perusahaan menjadi lebih dinamis sehingga menghasilkan kinerja perusahaan. Menurut Romney and Steinbart (2009), penerapan sistem informasi akuntansi di perusahaan dapat memberi nilai tambah (value added) bagi pemakai dalam bentuk penyediaan berbagai informasi keuangan untuk kegiatan perencanaan, pengendalian dan pengambilan keputusan perusahaan. Adanya nilai tambah SIA akan meningkatkan kualitas komitmen organisasional yang pada akhirnya dapat meningkatkan kinerja perusahaan secara keseluruhan. Kemudian Gelinas, et. al. (1993), menyatakan bahwa keberhasilan penerapan sistem informasi akuntansi dapat mendorong perbaikan dalam operasi bisnis sehari-hari dan dapat meningkatkan kualitas pengambilan keputusan perusahaan. Perbaikan operasi bisnis, peningkatan pengambilan kualitas keputusan manajerial, serta komitmen komitmen organisasional yang tinggi dapat di duga akan mempunyai pengaruh besar untuk pencapaian kinerja perusahaan.

Berdasarkan uraian di atas, maka kerangka pemikiran penelitian ini dapat digambarkan seperti Gambar 1 berikut ini.

Gambar 1. Kerangka Pemikiran

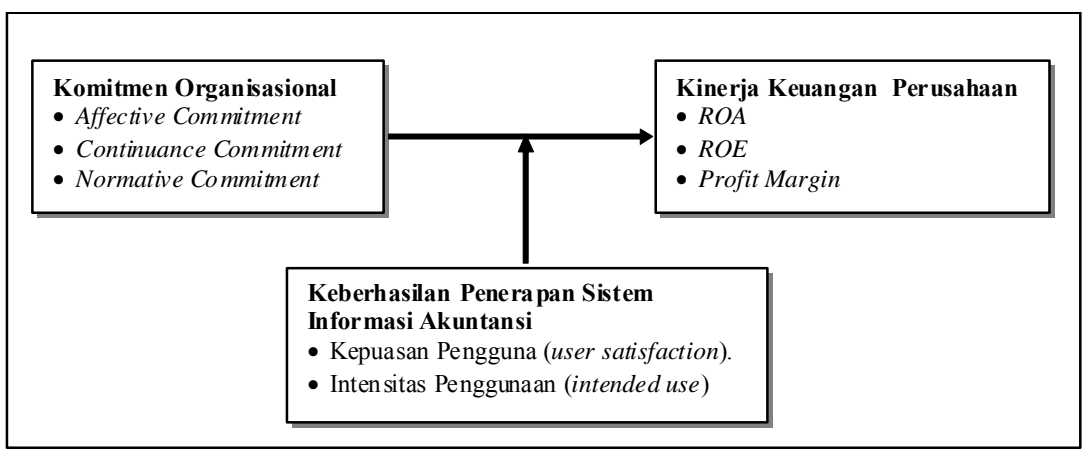

\section{HIPOTESIS}

Berdasarkan identifikasi masalah, kajian teoritis, dan pengembangan hipotesis yang telah dikemukakan, maka hipotesis penelitian ini adalah sebagai berikut:

1. Komitmen Organisasional berpengaruh positif dan signifikan terhadap 
Kinerja Keuangan Perusahaan.

2. Keberhasilan Penerapan SIA memperkuat pengaruh antara Komitmen Organisasional dan Kinerja Keuangan Perusahaan.

\section{METODE PENELITIAN}

\subsection{DESAIN PENELITIAN}

Jenis penelitian ini adalah penelitian verifikatif(verificative research) dan bersifat penjelas (explanatory research), karena penelitian ini bertujuan untuk melakukan verifikasi dan menjelaskan hubungan kausalitas antara berbagai variabel melalui pengujian hipotesis. Dari sisi pengumpulan data penelitian ini dapat disebut sebagai penelitian survei dan bersifat graunded research. Penelitian survei adalah metode pengumpulan data primer yang diperoleh secara langsung dari sumber asli, berupa penyebaran kuesioner yang diambil dari suatu sampel dalam sebuah populasi.

\subsection{OPERASIONALISASI VARIABEL}

Berikut ini diringkaskan variabel penelitian berikut dimensi, indikator dan skala pengukuran yang akan digunakan, seperti dalam Tabel 2. berikut:

Tabel 2. Operasionalisasi Variabel

\begin{tabular}{|c|c|c|c|c|}
\hline Variabel & Dimensi & Indikator & Skala & $\begin{array}{c}\text { No. } \\
\text { Kuesioner }\end{array}$ \\
\hline \multirow{3}{*}{$\begin{array}{c}\text { Komitmen } \\
\text { Organisasional } \\
(\mathrm{X} 1) \\
\text { Referen si: } \\
\text { Meyer and } \\
\text { Allen (1991); } \\
\text { dan Gibson, } \\
\text { et.al. (1994) }\end{array}$} & $\begin{array}{c}\text { Affective } \\
\text { Commitment }\end{array}$ & $\begin{array}{l}\text { - Tingkat sense of belonging } \\
\text { - Tingkat Emotional Attached } \\
\text { - Tingkat Personal Meaning }\end{array}$ & Ordinal & $1-12$ \\
\hline & $\begin{array}{l}\text { Continuance } \\
\text { Affective }\end{array}$ & $\begin{array}{l}\text { - Tingkat pertimbangan } \\
\text { pemilihan pekerjaan lain } \\
\text { - Tingkat motivasi mengejar } \\
\text { benefit } \\
\text { - Tingkat pertimbangan biaya } \\
\text { pindah pekerjaan }\end{array}$ & Ordinal & $13-18$ \\
\hline & $\begin{array}{c}\text { Normative } \\
\text { Commitment }\end{array}$ & $\begin{array}{l}\text { - Tingkat keyakinan untuk loyal } \\
\text { - Tingat keyakinan akan etika }\end{array}$ & Ordinal & $19-23$ \\
\hline \multirow{2}{*}{$\begin{array}{l}\text { Keberhasilan } \\
\text { Penerapan } \\
\text { Sistem } \\
\text { Informasi } \\
\text { Akun tansi (Y) } \\
\text { Referensi: } \\
\text { Delon and } \\
\text { McLean } \\
\text { (1992); Straub } \\
\text { et.al. (1995); } \\
\text { Gelderman } \\
\text { (1998) }\end{array}$} & $\begin{array}{l}\text { Kepuasan } \\
\text { Pengguna }\end{array}$ & $\begin{array}{l}\text { - Isi } \\
\text { - Akurasi } \\
\text { - Format } \\
\text { - Kemudahan dalam } \\
\text { penggunaan } \\
\text { - Ketepatan waktu }\end{array}$ & Ordinal & $36-47$ \\
\hline & $\begin{array}{c}\text { Inten sitas } \\
\text { Penggunaan }\end{array}$ & $\begin{array}{l}\text { - Frekwensi pen ggunaan } \\
\text { - Acuan dalam tugas sehari-hari }\end{array}$ & Ordinal & $48-49$ \\
\hline \multirow{3}{*}{$\begin{array}{c}\text { Kinerja } \\
\text { Keuangan } \\
\text { Perusahaan } \\
(\mathrm{Z}) \\
\text { Referensi: } \\
\text { Barker and } \\
\text { Cagwin } \\
(2000) \text {; dan } \\
\text { Gomes (2003) }\end{array}$} & ROA & $\begin{array}{l}\text { - } \mathrm{ROA}=\text { Laba Bersih setelah } \\
\text { pajak dibagi dengan total asset. }\end{array}$ & Rasio & - \\
\hline & ROE & $\begin{array}{l}\text { - } \mathrm{ROE}=\text { Laba Bersih setelah pajak } \\
\text { dibagi dengan total modal } \\
\text { saham. }\end{array}$ & Rasio & - \\
\hline & Prof it Margin & $\begin{array}{l}\text { Profit Margin=Laba Bersih } \\
\text { setelah pajak dibagi dengan } \\
\text { total pen jualan bersih }\end{array}$ & Rasio & - \\
\hline
\end{tabular}




\subsection{POPULASI DAN TEKNIK PENARIKAN SAMPEL}

Populasi sasaran penelitian ini adalah seluruh BUMN yang ada di Indonesia. Unit observasi/pengamatan penelitian ini adalah seluruh BUMN yang ada di Indonesia yang berjumlah 142 BUMN. Adapun teknik penarikan sampel dalam penelitian ini menggunakan sampling acak sederhana (simple random sampling). Ukuran sampel minimal dalam penelitian ini menggunakan teknik iterasi. Berdasarkan perhitungan iterasi diperoleh nilai sampel sebesar 38 BUMN di Indonesia.

\subsection{METODE ANALISIS DATA}

Analisis data dalam penelitian ini dilakukan dengan analisis deskriptif dan analisis verifikatif. Analisis verifikatif dalam penelitian ini menggunakan Moderated Regression Analysis (MRA) dengan bantuan Software SPSS 16. MRA adalah suatu metode regresi untuk melihat pengaruh interaksi antara dua variabel independen terhadap variabel dependen. Dengan memperhatikan koefisien regresi atas variabel interaksi maka dapat disimpulkan apakah dua variabel independen telah berinteraksi mempengaruhi variabel independen. Secara matematis persamaan regresi MRA dituliskan sebagai berikut:

$$
Y=\alpha+\beta_{1} \chi_{1}+\beta_{2} \chi_{2}+\beta_{3} \chi_{1} \chi_{2}+\varepsilon
$$

Keterangan :

$\begin{array}{ll}\mathrm{X}_{1}= & \text { Komitmen Organisasional } \\ \mathrm{X}_{2}= & \text { Keberhasilan Penerapan Sistem Informasi Akuntansi } \\ \mathrm{Y}= & \text { Kinerja Keuangan Perusahaan } \\ \mathrm{a}= & \text { Konstanta } \\ \mathrm{B}= & \text { Koefisien korelasi } \\ \mathrm{e}= & \text { Error }\end{array}$

\section{HASIL PENELITIAN}

\subsection{PENGARUH KOMITMEN ORGANISASIONAL TERHADAP KINERJA} KEUANGAN

Hasil pengujian regresi komitmen organisasional terhadap kinerja keuangan dengan menggunakan dimensi ROA, ROE, dan Profit Margin menunjukkan nilai R Square masing-masing sebesar 0,290 untuk ROA, 0,271 untuk ROE, dan 0,343 untuk Profit Margin. Dari masing-masing nilai R Square tersebut dapat disimpulkan bahwa variabel komitmen organisasional dapat menjelaskan sebesar 29,0\% untuk ROA, 27,1\% untuk ROE, dan 34,3\% untuk Profit Margin, sisanya variabel lain selain komitmen organisasional. Kemudian dari hasil pengujian Anova atau F test didapatkan nilai 14,734 dengan signifikansi sebesar 0,000 $(<0,05)$ untuk ROA, 13,416 dengan signifikansi sebesar $0,001(<0,05)$ untuk ROE, dan 18,818 dengan signifikansi sebesar $0,000(<0,05)$. Hal ini berarti bahwa model regresi yang dihasilkan dapat digunakan untuk memprediksi kinerja keuangan. 
Hasil uji t variable komitmen organisasional terhadap kinerja keuangan menunjukkan nilai koefisien parameter sebesar 3,838 dengan signifikansi sebesar $0,000(<0,05)$ untuk ROA, 3,663 dengan signifikansi sebesar 0,001 $(<0,05)$ untuk ROE, dan 4,338 dengan signifikansi sebesar 0,000 $(<0,05)$ untuk Profit Margin. Hasil pengujian $t$ test ini mengkonfirmasi bahwa komitmen organisasional berpengaruh positif dan signifikan terhadap kinerja keuangan perusahaan, baik untuk dimensi ROA, ROE, maupun dimensi Profit Margin. Dengan hasil ini dapat disimpulkan bahwa hipotesis pertama yang diajukan dalam penelitian ini diterima. Hal ini berarti bahwa semakin tinggi tingkat komitmen organisasional maka akan semakin tinggi pula tingkat kinerja keuangan perusahaan. Diterimanya hipotesis pertama dalam penelitian ini sekaligus mengkonfirmasi hasil penelitian sebelumnya yang telah dilakukan oleh Keller (1997), Chen (2004), Clercq and Rius (2007), dan Etty Murwaningsari (2008).

4.2. PENGARUH INTERAKSI KOMITMEN ORGANISASIONAL DAN KEBERHASILAN PENERAPAN SIA TERHADAP KINERJA KEUANGAN PERUSAHAAN.

Hasil pengujian pengaruh interaksi komitmen organisasional dan keberhasilan penerpan SIA terhadap kinerja keuangan perusahaan dengan menggunakan dimensi ROA, ROE, dan Profit Margin menunjukkan nilai R Square masingmasing sebesar 0,559 untuk ROA, 0,358 untuk ROE, dan 0,533 untuk Profit Margin. Dari masing-masing nilai R Square tersebut dapat disimpulkan bahwa variabel komitmen organisasional, keberhasilan penerapan SIA, dan interaksi kedua variabel dapat menjelaskan sebesar 55,90\% untuk ROA, sebesar 35,8\% untuk ROE, dan sebesar 53,3\% untuk Profit Margin, sisanya oleh variabel lain selain komitmen organisasional, keberhasilan penerapan SIA, dan interaksi kedua variabel tersebut. Kemudian dari hasil pengujian Anova atau F test didapatkan nilai 14,363 dengan signifikansi sebesar $0,000(<0,05)$ untuk ROA, 6,322 dengan signifikansi sebesar $0,002(<0,05)$ untuk ROE, dan 12,929 dengan signifikansi sebesar $0,000(<0,05)$. Hal ini berarti bahwa model regresi variabel komitmen organisasional, keberhasilan penerapan SIA, dan interaksi keduanya dapat digunakan untuk memprediksi kinerja keuangan baik dimensi ROA, ROE maupun Profit Margin.

Hasil uji t variabel interaksi komitmen organisasional dan keberhasilan penerapan SIA terhadap kinerja keuangan menunjukkan nilai koefisien parameter sebesar 2,988 dengan signifikansi sebesar $0,000(<0,05)$ untuk ROA, 0,387 dengan signifikansi sebesar $0,701(>0,05)$ untuk ROE, dan $-0,351$ dengan signifikansi sebesar 0,727 $(>0,05)$ untuk Profit Margin. Hasil pengujian t test ini mengkonfirmasi bahwa interaksi antara komitmen organisasional dan keberhasilan penerapan SIA berpengaruh positif dan signifikan terhadap kinerja keuangan khususnya untuk dimensi ROA, sedangkan untuk ROE dan Profit Margin tidak berpangaruh positif dan signifikan. Dengan hasil ini dapat disimpulkan bahwa hipotesis kedua yang diajukan dalam penelitian ini hanya dapat diterima untuk dimensi ROA sedangkan untuk dimensi ROE dan Profit 
Margin tidak dapat diterima. Hal ini berarti bahwa komitmen organisasional dan keberhasilan penerapan SIA berinteraksi atau bersama-sama mempengaruhi kinerja keuangan (ROA) perusahaan. Dengan kata lain dapat dikatakan bahwa keberhasilan penerapan SIA adalah variabel moderator untuk hubungan komitmen organisasional dan kinerja keuangan ROA, sedangkan untuk kinerja keuangan ROE dan Profit Margin tidak berperan sebagai variabel moderator.

Penulis menduga tidak signifikannya pengaruh interaksi antara komimen organisasional dan keberhasilan penerapan SIA terhadap dan kinerja keuangan khususnya dimensi ROE dan Proft Margin, disebabkan oleh kompleknya faktor yang mempengaruhi kinerja keuangan dan juga sebagai supporting system SIA tidaklah mempengaruhi kinerja secara langsung akan tetapi melalui variabelvariabel lain.

\section{SIMPULAN, KETERBATASAN DAN IMPLIKASI}

5.1 SIMPULAN

Simpulan penelitian ini adalah sebagai berikut:

1. Komitmen organisasional berpengaruh positif dan signifikan terhadap kinerja keuangan (dimensi ROA, ROE, dan Profit Margin).

2. Keberhasilan penerapan SIA memoderasi atau memperkuat pengaruh Komitmen Organisasional terhadap kinerja keuangan dimensi ROA, namun tidak memperkuat pengaruh terhadap kinerja keuangan dimensi ROE dan Profit Margin.

\subsection{KETERBATASAN}

Hasil penelitian ini menunjukkan beberapa keterbatasan yang mengurangi kesempurnaannya, antara lain:

a. Kemungkinan ada bias persepsi dari responden untuk pengukuran variabel moderating keberhasilan penerapan SIA karena menggunakan Manajer SIA sebagai responden dan bukan pengguna SIA.

b. Kelemahan dalam metode penarikan sampel penelitian yang menggunakan menggunakan acak sederhana (BUMN tidaklah berpopulasi).

\subsection{IMPLIKASI}

Hasil ini diharapkan mempunyai implikasi antara lain:

a) Untuk pengembangan ilmu akuntansi khususnya SIA dapat mendorong penelitian sejenis dengan menjadikan keberhasilan penerapan SIA sebagai variabel moderating untuk hubungan variabel-variabel lain.

b) Bagi praktek di BUMN hasil penelitian ini diharapkan dapat menjadi acuan dalam pengembangan SIA diperusahaan, karena keberhasilan penerapan SIA sebagai supporting system dapat menguatkan peran sistem-sistem manajemen yang lain. 


\section{DAFTAR PUSTAKA}

Agus Sartono. 2001. Manajemen Keuangan: Teori dan Aplikasi. Edisi Keempat. Yogyakarta: BPFE.

Azhar Susanto. 2007. Sistem informasi Manajemen: Konsep dan Pengembangannya. Edisi 3. Bandung: Lingga Jaya.

Barker, K.J., and Cagwin, D. 2004. New Evidence Relating TQM to Financial Performance: An Empirical Study Manufacturing Firms. Working Paper. December.

Cagwin, D., and Bouwman, M.J. 2000. The Association Between Activity Based Costing and Improvement in Financial Performance. Working paper, April 26.

Chen, Z.X., Tsui, A.S., and Farh, J.L. 2002. Loyality to Supervisors vs. Organizational Commitment: Relationships to Employee performance in China. Journal of Occupational and Organizational Psychology. 75: 339-356.

Clercq, D.D., and Rius, I.B. 2007. Organizational Commitment in Mexican Small and Medium-Sized Firms: The Role of Work Status, Organizational Climate, and Entrepreneurial Orientation. Journal of Small Business Management. 10(2): 185-210.

Delone, W.H., and McLean. 1992. Information Systems Success: The Quest for the Dependent Variable. Information Systems Research. 3(1): 60-95.

Drury, D.H., and Farhoomand, A.F. 1998. A Hierarchical Structural Model of Information System Success. Information System Journal. 36 (1/2): 2540.

Etty Murwaningsari. 2008. The Role of Organizational Commitment and Procedural Justice in Moderating the Relationship Between Budgetary Participation and Managerial Performance. Gadjah Mada International Journal of Business. 10(2): 185-210.

Fraser, L.M., and Ormiston, A. 1998. Understanding Financial Statement. Fifth Edition. USA: Prentice Hall International inc.

Gelderman, M. 1998. The Relation Between User Satisfaction, Usage of Information Systems and Performance. Information \& Management. 34: $11-18$ 
Gelinas, J.U., Allan, O.E., and William, W.P. 1993. Accounting Information System. Second Edition, Cincinnati, Ohio: South-Western Publishing Co.

Gibson, J.L., Invancevich, J.M., and Donnelly, J.M. 1994. Organization Behavior: Structure and Process. Seventh Edition, Boston: Homewood, Richard D. Irwin.

Gomes, F.C. 2003. Manajemen Sumber Daya Manusia. Yogyakarta: Andi Offset.

Keller, R.T. 1997. Job Involvement and Organizational Commitment as Longitudinal Predictors of Job Performance: A Study of Scientists and Engineers. Journal of Applied Psychology. 82 (4): 539-545.

Kettinger, W. J., and Lee, C.C. Perceived Service Quality and User Satisfaction with the Information Services Function. Decision Sciences. 25(5/6): 737765 .

Lee, J.J., and Kim, S.H. 1992. The Relationship Between Procedural Formalization in MIS Development and MIS Success. Information and Management, 22(2): 89-111.

Mathis, R.L., and Jackson, J.H. 2004. Human Resources Management. International Student Edition. South-Western, a division of Thompson Learning, Thompson Learning is a Trademark Used Herein Under License, In Singapore.

Meyer, J. P., and Allen, N. J. 1991. A Three-Component Conceptualization of Organizational Commitment. Human Resources Management Review. 1: $61-89$.

Mowday, R.T., Porter, L.W., and Steers, R.M. 1982. Employee-Organization Linkages. New York: Academic Press.

Romney, B.M., and Steinbart, J.P. 2009. Accounting Information System. Eleventh Edition. USA: Pearson Prentice Hall.

Salama, A.I. 2003. A Median Regression Analysis of the Relationship Between Environmental Reputation and Corporate financial performance: Empirical Evidence on UK Firms. A Paper Presented at the rRensselaer Polytechnic Institute Confrerence, New York: October.

Stolovitch, Harold, D., and Keeps, E.J. 1992, Handbook of Human Performance Technology A Comprehensive Guide for Analysis and Solving Performance Problem in Organizations. San Francisco: Jersey-Bass Publisher. 
Straub, et.al. 1995. Measuring System Usage: Implications for IS Theory Testing. Management Science, 41(8): 1328-1342.

Teguh Pambudi. 2006. Dan Karyawan Pun Memilih. Melalui <http:// 202.59.162.82/swamajalah/sajian/details.php?cid=1\&id=3870> [15/07/09].

Thong, J.Y.T., and Yap, C. 1996. Information Systems Effectiveness: A User Satisfaction Approach. Information Processing \& Management. 32(5): $601-610$

Torkzadeh G., and Doll, W.J. 1998. The Test-Retest Reliability of User Involvement Instruments. Information and Management. 26(1): 21-31. 


\section{LAMPIRAN:}

HASIL PENGUJIAN REGRESI

(1) REGRESI KOMITMEN ORGANISASIONAL TERHADAP KINERJA KEUANGAN

Variabel Dependen ROA

\begin{tabular}{|l|r|r|r|c|}
\hline Mod el & \multicolumn{1}{|c|}{ Rodel Sum mary } \\
\hline 1 & R Square & $\begin{array}{c}\text { Adjusted R } \\
\text { Square }\end{array}$ & $\begin{array}{c}\text { Std. Error of the } \\
\text { Estimate }\end{array}$ \\
\hline
\end{tabular}

ANOVA $^{\mathrm{b}}$

\begin{tabular}{|ll|r|r|r|r|r|}
\hline Mod el & & Sum of Squares & df & Mean Square & F & Sig. \\
\hline 1 & Regression & 1149.040 & 1 & 1149.040 & 14.734 & $.000^{\mathrm{a}}$ \\
& Residual & 2807.488 & 36 & 77.986 & & \\
& Total & 3956.527 & 37 & & & \\
\hline
\end{tabular}

a. Predictors: (Constant), Komitmen Organisasional

b. Dependent Variable: ROA

Coefficients $^{\mathrm{a}}$

\begin{tabular}{|c|c|c|c|c|c|}
\hline \multirow[b]{2}{*}{ Mod el } & \multicolumn{2}{|c|}{$\begin{array}{l}\text { Un standardized } \\
\text { Coefficien ts }\end{array}$} & \multirow{2}{*}{$\begin{array}{c}\begin{array}{c}\text { Standardized } \\
\text { Coefficients }\end{array} \\
\text { Beta }\end{array}$} & \multirow[b]{2}{*}{$\mathrm{t}$} & \multirow[b]{2}{*}{ Sig. } \\
\hline & $\mathrm{B}$ & Std. Error & & & \\
\hline 1 (Constant) & -22.476 & 7.407 & & -3.034 & .004 \\
\hline Komitmen Organisasional & .471 & .123 & .539 & 3.838 & .000 \\
\hline
\end{tabular}

a. Dependent Variable: ROA

Variabel Dependen ROE

\begin{tabular}{|c|c|c|c|c|}
\hline \multicolumn{5}{|c|}{ Model Summary } \\
\hline Mod el & $\mathrm{R}$ & R Square & $\begin{array}{l}\text { Adjusted R } \\
\text { Square }\end{array}$ & $\begin{array}{l}\text { Std. Error of the } \\
\text { Estimate }\end{array}$ \\
\hline 1 & $.521^{\mathrm{a}}$ & .271 & .251 & 12.51611 \\
\hline
\end{tabular}

\begin{tabular}{|c|c|c|c|c|c|}
\hline \multicolumn{6}{|c|}{ ANOVA $^{b}$} \\
\hline Model & Sum of Squares & $\mathrm{df}$ & Mean Square & $\mathrm{F}$ & Sig. \\
\hline Regression & 2101.670 & 1 & 2101.670 & 13.416 & $.001^{\mathrm{a}}$ \\
\hline Residual & 5639.511 & 36 & 156.653 & & \\
\hline Total & 7741.181 & 37 & & & \\
\hline
\end{tabular}

a. Predictors: (Constant), Komitmen Organisasional

b. Dependent Variable: ROE

Coefficients ${ }^{\mathbf{a}}$

\begin{tabular}{|c|c|c|c|c|c|}
\hline \multirow[b]{2}{*}{ Model } & \multicolumn{2}{|c|}{$\begin{array}{l}\text { Unstandardized } \\
\text { Coefficients }\end{array}$} & \multirow{2}{*}{$\begin{array}{l}\text { Standardized } \\
\text { Coefficien ts } \\
\text { Beta }\end{array}$} & \multirow[b]{2}{*}{$\mathrm{t}$} & \multirow[b]{2}{*}{ Sig. } \\
\hline & $\mathrm{B}$ & Std. Error & & & \\
\hline (Constant) & -29.223 & 10.499 & & -2.784 & .009 \\
\hline Komitmen Organisasional & .637 & .174 & .521 & 3.663 & .001 \\
\hline
\end{tabular}

a. Dependent Variable: ROE 
Variabel Dependen Profit Margin

Model Summary

\begin{tabular}{|l|c|r|r|c|}
\hline Model & $\mathrm{R}$ & $\mathrm{R}$ Square & $\begin{array}{c}\text { Adjusted R } \\
\text { Square }\end{array}$ & $\begin{array}{c}\text { Std. Error of the } \\
\text { Estimate }\end{array}$ \\
\hline 1 & $.586^{\mathrm{a}}$ & .343 & .325 & 9.05643 \\
\hline
\end{tabular}

a. Predictors: (Constant), Komitmen Organisasional

ANOVA $^{b}$

\begin{tabular}{|ll|r|r|r|r|r|}
\hline Model & & Sum of Squares & \multicolumn{1}{|c|}{ df } & Mean Square & \multicolumn{1}{l|}{ F } & \multicolumn{1}{c|}{ Sig. } \\
\hline 1 & Regression & 1543.454 & 1 & 1543.454 & 18.818 & $.000^{2}$ \\
& Residual & 2952.679 & 36 & 82.019 & & \\
& Total & 4496.133 & 37 & & & \\
\hline
\end{tabular}

a. Predictors: (Constant), Komitmen Organisasional

b. Dependent Variable: Profit Margin

Coefficients ${ }^{\mathrm{a}}$

\begin{tabular}{|c|c|c|c|c|c|}
\hline \multirow[b]{2}{*}{ Model } & \multicolumn{2}{|c|}{$\begin{array}{l}\text { Unstandardized } \\
\text { Coefficients }\end{array}$} & \multirow{2}{*}{$\begin{array}{c}\text { Standardized } \\
\text { Coefficients }\end{array}$} & \multirow[b]{2}{*}{$\mathrm{t}$} & \multirow[b]{2}{*}{ Sig. } \\
\hline & B & Std. Error & & & \\
\hline $1 \quad$ (Constant) & -25.949 & 7.597 & & -3.416 & .002 \\
\hline Komitmen Organisasional & .546 & .126 & .586 & 4.338 & .000 \\
\hline
\end{tabular}

a. Dependent Variable: Profit Margin

(1) REGRESI INTERAKSI VARIABEL INDEPENDEN TERHADAP DEPENDEN

Variabel Dependen ROA

\begin{tabular}{|l|r|r|r|c|}
\hline Model & \multicolumn{1}{|c|}{ R } & \multicolumn{1}{|c|}{ R Square } & Adjusted R S quare & $\begin{array}{c}\text { Std. Error of the } \\
\text { Estimate }\end{array}$ \\
\hline 1 & $.748^{\mathrm{a}}$ & .559 & .520 & 7.16419 \\
\hline
\end{tabular}

a. Predictors: (Constant), Interaksi Keber_SIA dan Komit_Org, Komitmen

Organisasional, Keberhasilan Penerapan SIA

$\operatorname{ANOVA}^{\mathrm{b}}$

\begin{tabular}{|l|r|r|r|r|r|}
\hline Model & Sum of Squares & \multicolumn{1}{c|}{ df } & Mean Square & F & \multicolumn{1}{c|}{ Sig. } \\
\hline $1 \quad$ Regression & 2211.457 & 3 & 737.152 & 14.362 & $.000^{\mathrm{a}}$ \\
Residual & 1745.070 & 34 & 51.326 & & \\
\multicolumn{1}{|l|}{ Total } & 3956.527 & 37 & & & \\
\hline
\end{tabular}

a. Predictors: (Constant), Interaksi Keber_SIA dan Komit_Org, Komitmen Organisasional, Keberhasilan Penerapan SIA

b. Dependent Variable: ROA

Coefficients $^{\mathrm{a}}$

\begin{tabular}{|c|c|c|c|c|c|}
\hline \multirow[b]{2}{*}{ Model } & \multicolumn{2}{|c|}{$\begin{array}{l}\text { Unstandardized } \\
\text { Coefficients }\end{array}$} & \multirow{2}{*}{$\begin{array}{c}\text { Standardized } \\
\text { Coefficients }\end{array}$} & \multirow[b]{2}{*}{$\mathrm{t}$} & \multirow[b]{2}{*}{ Sig. } \\
\hline & B & Std. Error & & & \\
\hline (Constant) & 73.463 & 35.715 & & 2.057 & .047 \\
\hline Komitmen Organisasional & -1.422 & .583 & -1.628 & -2.438 & .020 \\
\hline Kebe masilan Penerapan SIA & -2.503 & 1.022 & -2.147 & -2.449 & .020 \\
\hline $\begin{array}{l}\text { Interaksi Keber_SIA dan } \\
\text { Komit_Org }\end{array}$ & .048 & .016 & 3.930 & 2.988 & .005 \\
\hline
\end{tabular}

a. Dependent Variable: ROA 


\section{Variabel Dependen ROE}

\begin{tabular}{|c|c|c|c|c|}
\hline \multicolumn{5}{|c|}{ Model Summary } \\
\hline Model & $\mathrm{R}$ & R Square & Adjusted R Square & $\begin{array}{l}\text { Std. Error of the } \\
\text { Estimate }\end{array}$ \\
\hline 1 & $.598^{\mathrm{a}}$ & .358 & .301 & 12.08941 \\
\hline
\end{tabular}

Organisasional, Keberhasilan Penerapan SIA

ANOVA $^{\mathrm{b}}$

\begin{tabular}{|l|r|r|r|r|r|}
\hline Model & Sum of Squares & df & Mean Square & F & \multicolumn{1}{c|}{ Sig. } \\
\hline $1 \quad$ Regression & 2771.950 & 3 & 923.983 & 6.322 & $.002^{2}$ \\
Residual & 4969.231 & 34 & 146.154 & & \\
Total & 7741.181 & 37 & & & \\
\hline
\end{tabular}

a. Predictors: (Constant), Interaksi Keber_SIA dan Komit_Org, Komitmen

Organisasional, Keberhasilan Penerapan SIA

b. Dependent Variable: ROE

Coefficients $^{\mathrm{a}}$

\begin{tabular}{|c|c|c|c|c|c|}
\hline \multirow[b]{2}{*}{ Model } & \multicolumn{2}{|c|}{$\begin{array}{l}\text { Unstandardized } \\
\text { Coefficients }\end{array}$} & \multirow{2}{*}{$\begin{array}{c}\text { Standardized } \\
\text { Coefficients } \\
\text { Beta }\end{array}$} & \multirow[b]{2}{*}{$\mathrm{t}$} & \multirow[b]{2}{*}{ Sig. } \\
\hline & B & Std. Error & & & \\
\hline $1 \quad$ (Constant $)$ & -15.565 & 60.268 & & -.258 & .798 \\
\hline Komitmen Organisasional & .073 & .984 & .060 & .074 & .941 \\
\hline Keberhasilan Penerapan SIA & -.125 & 1.724 & -.077 & -.072 & .943 \\
\hline $\begin{array}{l}\text { Interaksi Keber_SIA dan } \\
\text { Komit Org }\end{array}$ & .011 & .027 & .614 & .387 & .701 \\
\hline
\end{tabular}

Variabel Dependen Profit Margin

\begin{tabular}{|c|c|c|c|c|}
\hline \multicolumn{5}{|c|}{ Model Summary } \\
\hline Model & $\mathrm{R}$ & R Square & Adjusted R Square & $\begin{array}{l}\text { Std. Error of the } \\
\text { Estimate }\end{array}$ \\
\hline 1 & $.730^{\mathrm{a}}$ & .533 & .492 & 7.85940 \\
\hline
\end{tabular}

a. Predictors: (Constant), Interaksi Keber_SIA dan Komit_Org, Komitmen

Organisasional, Keberhasilan Penerapan SIA

\begin{tabular}{|l|r|r|r|r|r|}
\hline Model & Sum of Squares & df & Mean Square & F & \multicolumn{1}{c|}{ Sig. } \\
\hline $1 \quad$ Regression & 2395.949 & 3 & 798.650 & 12.929 & $.000^{\mathbf{a}}$ \\
\cline { 2 - 4 } & 2100.184 & 34 & 61.770 & & \\
\multicolumn{1}{|c|}{ Residual } & 4496.133 & 37 & & & \\
\hline
\end{tabular}

a. Predictors: (Constant), Interaksi Keber_SIA dan Komit_Org, Komitmen

Organisasional, Keberhasilan Penerapan SIA

b. Dependent Variable: Profit Margin

Coefficients $^{\mathrm{a}}$

\begin{tabular}{|c|c|c|c|c|c|}
\hline \multirow[b]{2}{*}{ Model } & \multicolumn{2}{|c|}{$\begin{array}{l}\text { Unstandardized } \\
\text { Coefficients }\end{array}$} & \multirow{2}{*}{$\frac{\begin{array}{l}\text { Standardized } \\
\text { Coefficients }\end{array}}{\text { Beta }}$} & \multirow[b]{2}{*}{$\mathrm{t}$} & \multirow[b]{2}{*}{ Sig. } \\
\hline & $\mathrm{B}$ & Std. Error & & & \\
\hline 1 (Constant) & -50.077 & 39.181 & & -1.278 & .210 \\
\hline Komitmen Orga nisasional & .550 & .640 & .590 & .859 & .396 \\
\hline Keberhasilan Penerapan SIA & 1.001 & 1.121 & .805 & .893 & .378 \\
\hline $\begin{array}{l}\text { Interaksi Keber_SIA dan } \\
\text { Komit_Org }\end{array}$ & -.006 & .018 & -.476 & -.351 & .727 \\
\hline
\end{tabular}

a. Dependent Variable: Profit Margin 